\title{
Osteopontin as a biomarker for osteosarcoma therapy and prognosis (Review)
}

\author{
XINGWEN HAN ${ }^{1}$, WENJI WANG ${ }^{1}$, JINGJING HE ${ }^{2}$, LEI JIANG ${ }^{3}$ and XUN $\mathrm{LI}^{4}$ \\ ${ }^{1}$ Department of Orthopedics, First Hospital of Lanzhou University; ${ }^{2}$ Department of Liver Diseases, \\ Second Hospital of Lanzhou University; Departments of ${ }^{3}$ Oncology Surgery and ${ }^{4}$ General Surgery, \\ First Hospital of Lanzhou University, Lanzhou, Gansu 730000, P.R. China
}

Received April 1, 2018; Accepted November 16, 2018

DOI: $10.3892 / \mathrm{ol} .2019 .9905$

\begin{abstract}
Osteosarcoma (OS) is the most common bone malignancy, and is particularly prevalent in children and adolescents. OS is an aggressive tumor with a tendency to metastasize and invade to para-carcinoma tissues. The primary treatment for this tumor is a combination of surgery and chemotherapy. However, the prognosis remains poor due to chemoresistance and early metastasis. Osteopontin (OPN), a multifunctional secreted protein, has emerged as an important potential biomarker for diagnosing and treating cancer. The overexpression of OPN has been found in numerous malignant tumors, including breast, lung, gastric and ovarian cancer, as well as melanoma. Recent studies have suggested that OPN may provide an important function in the diagnosis and treatment of OS. The present review summarizes current knowledge and progress in understanding the potential role of OPN as a biomarker in OS.
\end{abstract}

\section{Contents}

1. Introduction

2. Structural and functional characteristics of OPN

3. OPN expression in common solid tumors

4. Signaling pathways that may be activated by OPN in common tumors

5. OPN expression in OS

6. OPN as a biomarker in OS prognosis and therapy

7. Future directions

8. Conclusion

Correspondence to: Professor Xun Li, Department of General Surgery, First Hospital of Lanzhou University, 1 Donggang West Road, Lanzhou, Gansu 730000, P.R. China

E-mail: 1xdr21@126.com

Key words: osteopontin, osteosarcoma, metastasis, prognosis, biomarker, therapy

\section{Introduction}

Osteosarcoma (OS) is the most frequently occurring bone malignancy and the second leading cause of cancer-associated mortality in children and adolescents (1). The worldwide OS incidence rates are 4 and 5 cases per million individuals per year at the ages of 0-14 and 0-19 years, respectively. The incidence rate is higher in males than females (5.4 vs. 4.0 cases per million individuals per year, respectively). There are two peaks in OS incidence against age, with the first peak occurring between the ages of 10 and 14, and coinciding with the rapid development period of adolescence, indicating a strong association between adolescent growth and OS. The second peak occurs over the age of 65 years (2). The majority of OS originates from the long bones and $50 \%$ of cases occur in the region of the knee, including the distal femur and proximal tibia (3). OS is highly invasive and has a metastatic rate of $\sim 20 \%$, with the most common target for metastasis being the lungs (4).

The primary treatment is a combination of surgery and chemotherapy, including removing primary tumors and occasionally distant metastatic tumors with or without adjuvant chemotherapy (5). Surgical procedures for OS patients include amputation of the limb or limb salvage, which is determined based on the stage of OS. Limb salvage is performed on patients with lower grade OS, as the prognosis is similar to that of amputation (6). The drugs used for standard adjuvant chemotherapy are methotrexate, doxorubicin and cisplatin (7-9). However, early metastasis can lead to treatment failure and mortality $(10,11)$. The prognosis for patients with metastatic tumors is substantially poorer than that for patients with primary tumors only. The 5-year survival rate is reported to be $27.4 \%$ for patients with metastases at the initial diagnosis and $70 \%$ for patients without metastases (3).

Although the 5-year survival rate of a number of other cancer types has increased with an earlier diagnosis and improved treatments, the clinical outcomes for OS have not shown comparable improvement (12). Therefore, improvements in OS diagnosis and treatment are urgently required. The identification of a biomarker to predict early metastasis would represent a revolutionary breakthrough for OS diagnosis and treatment (13-15). Biomarkers are usually detectable in the blood or other bodily fluids, and in the tissues, and are 
typically tumor type-specific or sensitive to a particular bodily response that is associated with the presence of a cancer (16-19), including $\alpha$-fetoprotein in hepatocellular carcinoma, cancer antigen (CA)153 in breast cancer and CA125 in ovarian cancer diagnoses. Osteopontin (OPN) was first described as a marker of transformation of epithelial cells in 1979 (20). During the following 38 years, the role of OPN in the development of human tumors, as an indicator of malignancy and as a potential prognostic factor for clinical outcomes, has been investigated. The present review will comprehensively summarize progress in this area and propose future study directions regarding the role of OPN as a biomarker for OS based on its structure and function, as well as its association with the carcinoma.

\section{Structural and functional characteristics of OPN}

OPN is a chemokine-like, calcified extracellular matrix-associated protein that was first identified in bone. The multifaceted roles of OPN were intensively investigated following its discovery $(21,22)$. Human OPN, which consists of 314 amino acid residues, is a highly negatively charged protein that appears to lack complexity in its secondary structure (23). Human OPN contains a number of highly conserved structural elements, including serine-valine-valine-tyrosine-glycine-leucine-arginine and arginine-glycine-aspartate domains for integrin binding, a calcium binding site and heparin binding domains for mediating extracellular matrix receptor III (CD44 antigen) binding (24). There are five isoforms of OPN, which are encoded by five transcript variants derived from alternative splicing of the transcript encoded by the secreted phosphoprotein 1 gene (also known as OPN). OPN-a is the full-length isoform, OPN-b lacks exon 5 and OPN-c lacks exon 4, whereas isoforms 4 and 5 lack two alternate in-frame exons. OPN is a secreted extracellular glycophosphoprotein; it is usually extensively post-translationally modified by glycosylation, phosphorylation and sulfation, plus a number of cross-linking and proteolytic processes (25-27). High expression of OPN is found in osteoblasts, osteoclasts, vascular, smooth and skeletal muscle cells, lymphocytes, endothelial cells, neural cells and certain carcinoma cells.

\section{OPN expression in common solid tumors}

Tumor progression is dependent on the proliferation and metastasis of tumor cells, and leads to an increased risk of mortality in patients with OS. Therefore, it is imperative that a reliable biomarker for early tumor diagnosis and treatment is found. A large number of studies on different tumor types have shown that OPN serves a unique role in the proliferation and metastasis of malignant tumor cells (Table I), indicating that OPN may be a potent biomarker for cancer. Overexpression of OPN is associated with patient survival and the effect of therapeutic treatment, including surgery, chemotherapy or radiotherapy, in lung cancer (28-37). Higher OPN levels are associated with a poor prognosis, and OPN is a predictor of malignancy and poor outcomes following neoadjuvant chemotherapy in breast cancer (38-43). An elevated OPN level is associated with lymph node metastasis, Tumor-Node-Metastasis stage, depth of invasion, tumor size and distant metastasis in gastrointestinal cancer (44-62). OPN can be used as a marker of malignancy and multidrug resistance in genitourinary tumors (63-75).

\section{Signaling pathways that may be activated by OPN in common tumors}

As aforementioned, OPN is overexpressed in numerous tumor types and is associated with a poor prognosis, metastasis and therapy failure, suggesting that OPN may have marked clinical value in the treatment of malignant tumors. A number of studies (76-80) have addressed the mechanisms and possible signaling pathways involved in OPN-mediated tumor malignancy. Interactions between OPN and integrin promote tumor cell growth and angiogenesis. The interaction between OPN and hypoxia inducible factor $2 \alpha(\mathrm{HIF} 2 \alpha)$ promotes the expression of E-cadherin and vimentin to activate the epithelial-mesenchymal transformation (EMT) pathway, which stimulates tumor cell metastasis and metastatic colonization (76). OPN regulates HIF1 $\alpha$-dependent vascular endothelial growth factor (VEGF) expression via integrin-linked kinase/protein kinase $\mathrm{B}-\mathrm{mediated}$ activation of the $\mathrm{p} 65$ subunit of nuclear factor- $\kappa \mathrm{B}$ $(\mathrm{NF}-\kappa \mathrm{B})$, and thus increases tumor angiogenesis. OPN induces cytochrome oxidase subunit 2 and prostaglandin E2 secretion through extracellular signal-regulated kinase and p38 mitogen-activated protein kinase-dependent activator protein 1 activation via integrin $\alpha 9 \beta 1$, and thus enhances tumor cell motility and angiogenesis. OPN binds to its receptor integrin $\alpha 4 \beta 1$ and induces tumor relapse via the phosphorylation of inhibitor of NF- $\kappa \mathrm{B}$ kinase (IKK $\beta$ ), which is followed by increased nuclear translocation of p50 and p65 subunits of $\mathrm{NF}-\kappa \mathrm{B}$ (77-79). Certain studies have demonstrated that OPN stimulates cancer stem cell-mediated tumor progression by inducing high expression of CD44 isoforms containing exon v6 (CD44v6) through the WNT/ $\beta$-catenin pathway (80). Fig. 1 outlines the signaling pathways by which OPN may affect tumor cell proliferation, invasion, metastasis and angiogenesis.

\section{OPN expression in OS}

Expression of OPN in bone tissues is critical for the status of osteoblasts. OPN is necessary for modulating osteoblast differentiation through integrin $\alpha v \beta 3$-mediated cell signaling (81). Reducing OPN expression inhibits the differentiation of mesenchymal stem cells or immature osteoblasts into mature osteoblasts while preserving the characteristics of immature osteoblastic-like cells, which may lead to OS (11). Changes in OPN levels may be associated with differentiation, growth and differentiation abnormalities in OS cells. A decreased level of OPN in osteoblasts is involved in the progression of OS via OPN-downregulated osteoblastic differentiation from mesenchymal stem cells (82). Lower levels of OPN expression in OS cells indicate that the majority of OS cells fail to undergo terminal osteogenic differentiation, thereby promoting OS growth (83). However, an elevated level of OPN in tumor cells or stromal cells has been reported to enhance the metastatic ability of OS (84).

The effect of OPN on the proliferation and migration of OS cells has been investigated in vitro. OPN overexpression stimulates OS cell proliferation in a dose-dependent manner, facilitates cyclin A expression in OS cells to accelerate the cell 
Table I. Expression and role of osteopontin in common solid tumors.

\begin{tabular}{|c|c|c|c|c|}
\hline Human tumor & Expression and role & Samples & Examination methods & (Refs.) \\
\hline Lung cancer & $\begin{array}{l}\text { Increased OPN was associated with } \\
\text { patient survival and the effect of } \\
\text { treatment }\end{array}$ & $\begin{array}{l}\text { Tumor tissue, patient } \\
\text { plasma and normal tissues }\end{array}$ & $\begin{array}{l}\text { RT-qPCR and/or western } \\
\text { blot analysis }\end{array}$ & $(28-37)$ \\
\hline Breast cancer & $\begin{array}{l}\text { Increased OPN was associated with } \\
\text { poor prognosis. OPN served a functional } \\
\text { role in malignancy and the prediction } \\
\text { of outcomes following neoadjuvant } \\
\text { chemotherapy }\end{array}$ & $\begin{array}{l}\text { Carcinoma, patient plasma } \\
\text { and control group }\end{array}$ & $\begin{array}{l}\text { Western blot analysis and/or } \\
\text { immunohistochemistry }\end{array}$ & $(38-43)$ \\
\hline $\begin{array}{l}\text { Gastrointestinal } \\
\text { cancer }\end{array}$ & $\begin{array}{l}\text { Increased OPN was associated with } \\
\text { lymph node metastasis, TNM stage, } \\
\text { depth of invasion, tumor size and } \\
\text { distant metastasis }\end{array}$ & $\begin{array}{l}\text { Tumor tissue, normal } \\
\text { tissue }\end{array}$ & $\begin{array}{l}\text { RT-qPCR and/or western } \\
\text { blot analysis }\end{array}$ & $(44-62)$ \\
\hline $\begin{array}{l}\text { Genitourinary } \\
\text { tumor }\end{array}$ & $\begin{array}{l}\text { OPN can be used as a marker of } \\
\text { malignancy and multidrug resistance }\end{array}$ & $\begin{array}{l}\text { Tumor tissue, cell line } \\
\text { and patient plasma }\end{array}$ & $\begin{array}{l}\text { RT-qPCR and/or western } \\
\text { blot analysis }\end{array}$ & $(63-75)$ \\
\hline
\end{tabular}

OPN osteopontin; TNM, Tumor-Node-Metastasis; RT-qPCR, reverse transcription-quantitative polymerase chain reaction.

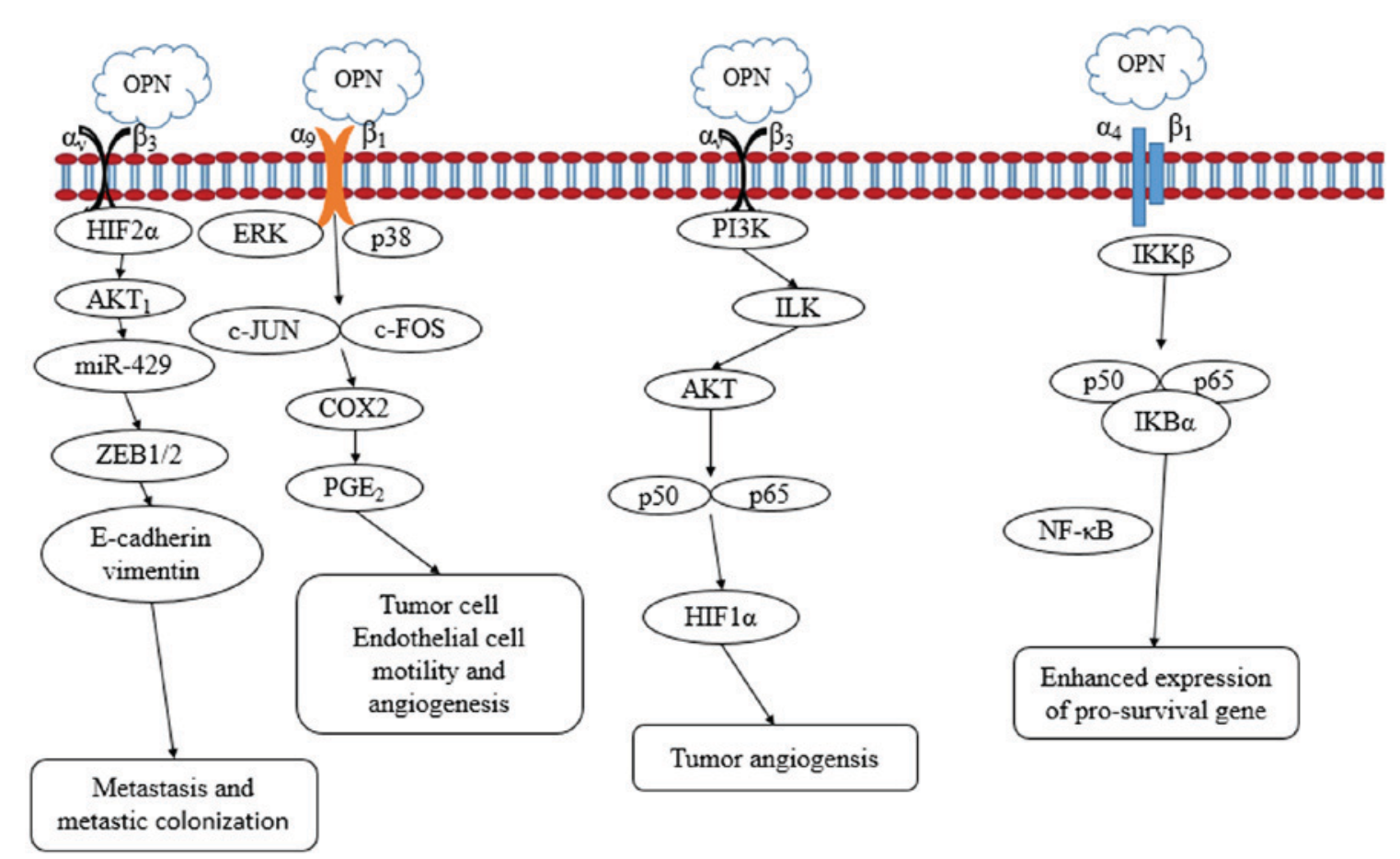

Figure 1. OPN-integrin interaction promotes tumor growth, angiogenesis and metastasis. OPN regulates HIF2 $\alpha$, increases the expression of E-cadherin and vimentin, and activates the epithelial-mesenchymal transformation pathway, which can stimulate tumor cell metastasis and metastatic colonization. OPN regulates HIF1 $\alpha$-dependent VEGF expression via inducing ILK/AKT1-mediated NF- $\mathrm{kB}$ p65 activation, and thus increasing tumor angiogenesis; OPN induces COX2 and PGE2 secretion through ERK- and p38-dependent c-JUN activation via $\alpha 9 \beta 1$-integrin, hence enhancing tumor cell motility and angiogenesis; OPN binds to its receptor $\alpha 4 \beta 1$ integrin, inducing the phosphorylation of IKK $\beta$ and increasing nuclear translocation of p50 and p65 subunits of NF-kB. OPN, osteopontin; HIF1 $\alpha / 2 \alpha$, hypoxia inducible factor $1 \alpha / 2 \alpha$; MET pathway, MET proto-oncogene; VEGF, vascular endothelial growth factor; ILK,

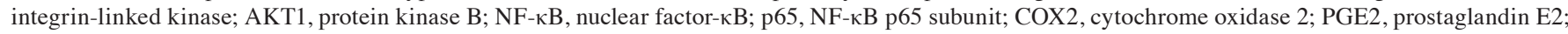
ERK, extracellular signal-regulated kinase; $\mathrm{p} 38$, mitogen-activated protein kinase; c-JUN, transcription factor activator protein 1; IKK $\beta$, inhibitor of NF- $\mathrm{KB}$ subunit $\beta$; p50, NF-кB DNA binding subunit; miR-429, microRNA-429; ZEB1/2, zinc finger E-box-binding homeobox 1/2; c-FOS, FOS proto-oncogene; PI3K, phosphoinositide-3-kinase; IKB $\alpha$, inhibitor of NF-kB subunit $\alpha$.

cycle and prompts transmembrane migration of OS cells (85). OPN also promotes the formation of OS in vivo. Overexpression of OPN antisense RNA in OS-732 cell xenografts was found to reduce the tumorigenicity of OS-732 cells in nude mice (86).
The small calcium-binding protein S100A4 is associated with tumor metastasis progression. Extracellular S100A4 may increase expression of the enzymes of the plasminogen activator system and matrix metalloproteinase (MMP) family, 


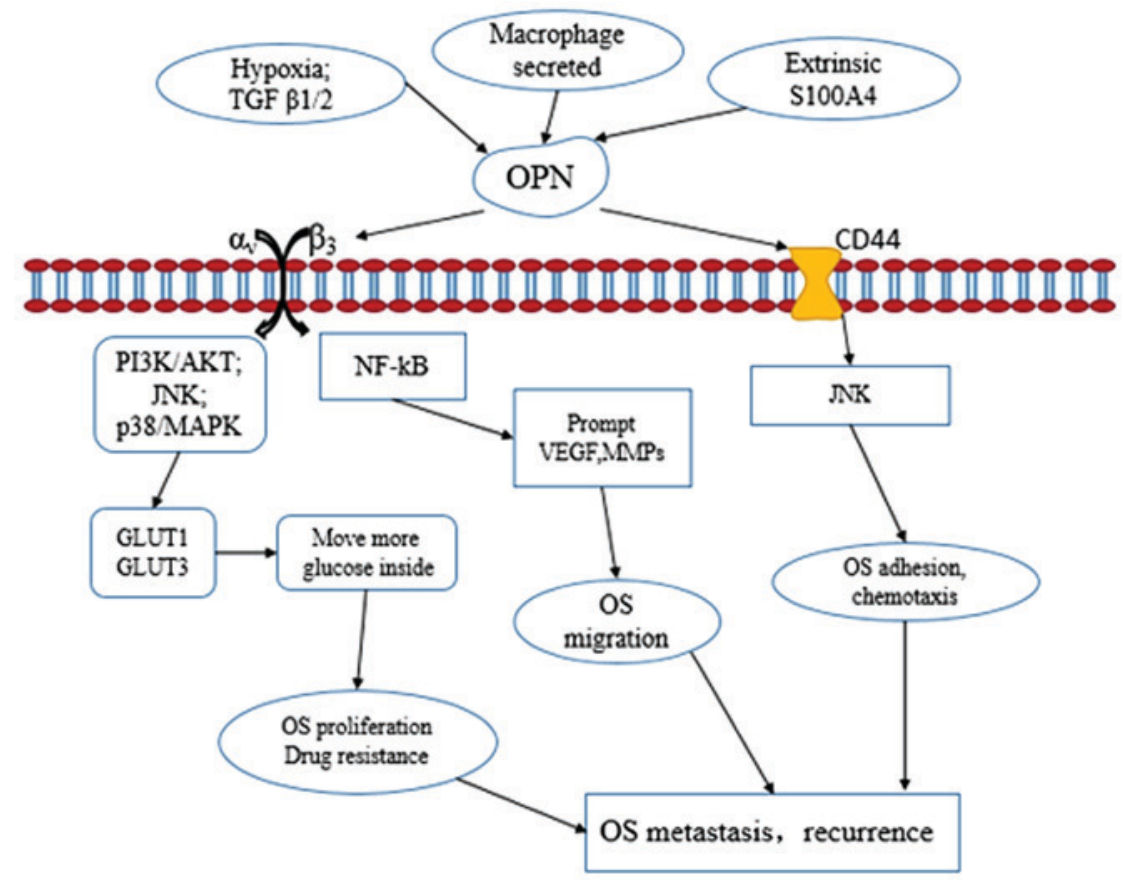

Figure 2. Central role of OPN in enhancing cell proliferation, drug resistance, migration and adhesion in OS. Various factors, including hypoxia, TGF $31 / 2$ and S100A4 increase OPN level to augment the expression of GLUT1/3, VEGF and MMPs through integrin and/or CD44 pathways, enhancing proliferation, drug resistance, migration and adhesion in OS, and thus contributing to OS metastasis and/or recurrence. OPN, osteopontin; OS, osteosarcoma; TGF $1 / 2$, transforming growth factor $\beta 1 / 2$; S100A4, calcium-binding protein A4; GLUT1/3, glucose transporter 1/3; VEGF, vascular endothelial growth factor; MMP, matrix metalloproteinase; CD44, extracellular matrix receptor III; PI3K, phosphoinositide-3-kinase; AKT, protein kinase B; JNK, c-JUN N-terminal kinase; p38, mitogen-activated protein kinase; NF- $\mathrm{B}$, nuclear factor- $\kappa \mathrm{B}$.

particularly urokinase plasminogen activator and MMP-13. S100A4 increases the mobility and invasion of OS cells in vitro. S100A4 siRNA molecules inhibit OPN expression and reduce protease expression and invasion capacity in OS cells, suggesting that OPN is a downstream target of S100A4 signaling, and that OPN may also be associated with OS metastasis (87). Hypoxia is a major regulator of tumor development and aggression (88). Glucose is a source of metabolic energy that maintains the proliferation and survival of tumor cells. Glucose transporters (GLUTs) move glucose into the cytoplasm to promote aerobic glycolysis, also known as the Warburg effect $(89,90)$. A hypoxia-mimetic agent was found to promote the expression of OPN, GLUT1, GLUT2 and GLUT3. Exogenous OPN may stimulate expression of GLUT1 and GLUT3, increasing glucose uptake into hypoxic OS cells and enhancing OS cell viability (91).

MicroRNA-4262 (miR-4262) has been identified as a key regulator of tumorigenesis, cancer cell growth and metastasis in OS. The expression of miR-4262 in OS tissue samples is decreased and the level of OPN is increased compared with matched adjacent non-tumor tissues. In addition, miR-4262 and OPN are negatively correlated in OS specimens. Overexpression of miR-4262 was found to inhibit OPN-mediated cell invasion, whereas miR-4262 depletion increased OPN-mediated cell invasion in OS cells (92). As aforementioned, studies have shown that OPN is abnormally expressed in OS, and it is associated with the proliferation, metastasis and prognosis of the disease. OPN may be used as a biomarker of the prognosis and metastasis of OS. However, identifying the specific mechanism of its action requires further investigation. These observations indicate that the altered expression of OPN may be associated with OS progression and metastasis. Fig. 2 outlines the possible signaling pathways through which OPN may affect OS metastasis and recurrence.

\section{OPN as a biomarker in OS prognosis and therapy}

OS is a highly malignant tumor, and the majority of patients undergo metastasis prior to diagnosis, resulting in a poor prognosis (12). OPN serves a role in metastasis and prognosis in several malignant tumors. However, our current understanding regarding the use of OPN as a biomarker for OS is insufficient. Transforming growth factor- $\beta 1$ (TGF- $\beta 1$ ) regulates several extracellular matrix proteins and promotes the expression of OPN, increasing the malignancy of OS cells (93). In a study with 11 OS patients and 29 healthy controls, mRNA levels of osteocalcin, osteonectin, OPN and type I collagen in peripheral blood samples were increased in $91 \%$ of OS patients, but were increased in only $35 \%$ of healthy subjects. Additionally, 6 OS patients with peripheral blood OPN mRNA expression exceeding the highest level found in healthy subjects developed clinical metastasis within 12 months after diagnosis. Elevated peripheral blood OPN mRNA level may result from an increased number of circulating OS cells. These observations indicate that peripheral blood OPN level may be used as a biomarker for diagnosing OS micrometastases and evaluating prognosis (94). By contrast, another study found that OPN expression in bone biopsies could not provide predictive information regarding outcomes in OS patients. Bone specimens from 57 OS patients and 11 osteoblastoma patients were used to analyze the expression of OPN and VEGF with immunohistochemistry. In OS samples, OPN and VEGF expression 
were correlated with each other. High VEGF expression in OS patients showed a tendency to shorten overall survival time, but OPN had no influence on patients overall or disease-free survival times (95). The discrepancy between the two studies may be due to differences between OPN mRNA versus protein expression, the type of tissue in which OPN was measured and the evaluation of clinical outcome parameters, including metastasis or survival period. Peripheral blood OPN has the potential to be useful as a biomarker for OS and should be further evaluated in well-controlled studies.

\section{Future directions}

Although the expression level of OPN in OS biopsies does not appear to be a prognostic marker for OS (95), peripheral blood OPN expression has the potential to be a useful biomarker for OS (94). However, substantial research is required to validate the role of peripheral blood OPN expression level as a biomarker for OS. A reliable method to detect the expression level of OPN in peripheral blood is required. A clinical study using sufficient blood samples from OS patients and healthy controls should be conducted, and a standard reference value of OPN in the blood should be obtained through analyzing the expression of OPN in normal blood samples. The association between OPN and the prognosis of the patients with OS must also be validated. Such a study could provide answers to the following issues: i) Whether elevated OPN in the peripheral blood is an outcome of increased circulating OS cells; and ii) whether elevated OPN in the peripheral blood is correlated with the number of circulating OS cells, EMT status, metastasis, OS grade, disease-free survival rate or any other clinical parameters.

OPN is a secreted protein that may be derived from the primary OS tumor, but the presence of RNase makes OPN mRNA unstable in the blood. Therefore, methods for assessing OPN protein, such as ELISA, should be evaluated to detect OPN in patient blood specimens. Validation of peripheral blood OPN expression as a predictive prognostic marker for OS may improve clinical outcomes and quality of life for patients with OS.

\section{Conclusion}

The high degree of malignancy and early metastasis underscore the urgency of finding a sensitive marker to improve the diagnosis, treatment and prognosis of patients with OS. The preset review focuses on the potential value of OPN in peripheral blood as a biomarker for OS. OPN may be used as a biomarker for early diagnosis, therapeutic effectiveness and prognosis in a number of other tumors. OPN serves an important role in OS cell proliferation, invasion and migration in vitro, and in mice xenografts. In clinical studies, peripheral blood OPN has also been associated with micrometastases in patients with OS. However, the role of peripheral blood OPN in diagnosis, therapeutic evaluation and as a prognostic biomarker for OS must be further validated in well-controlled clinical studies.

\section{Acknowledgements}

Not applicable.

\section{Funding}

This review was supported by the Gansu Province Natural Science Foundation (grant no. 1606RJZA126) and the Gansu Province Science-Technology Plan Foundation, China (grant no. 17JR5RA196).

\section{Availability of data and materials}

Not applicable.

\section{Authors' contributions}

JH performed the data collection. WW and XL conceived the study, analyzed the data, and drafted the manuscript. LJ critically revised the manuscript. XH was responsible for the conception and writing of the manuscript. All authors read and approved the final manuscript.

\section{Ethics approval and consent to participate}

Not applicable.

\section{Patient consent for publication}

Not applicable.

\section{Competing interests}

The authors declare that they have no competing interests.

\section{References}

1. Singh K, Mukherjee AB, De Vouge MW and Mukherjee BB: Differential processing of osteopontin transcripts in rat kidneyand osteoblast-derived cell lines. J Biol Chem 267: 23847-23851, 1992.

2. Ottaviani G and Jaffe N: The epidemiology of osteosarcoma. Cancer Treat Res 152: 3-13, 2009.

3. Simpson S, Dunning MD, de Brot S, Grau-Roma L, Mongan NP and Rutland CS: Comparative review of human and canine osteosarcoma: Morphology, epidemiology, prognosis, treatment and genetics. Acta Vet Scand 59: 71, 2017.

4. Longhi A, Errani C, De Paolis M, Mercuri M and Bacci G: Primary bone osteosarcoma in the pediatric age: State of the art Cancer Treat Rev 32: 423-436, 2006.

5. Selmic LE, Burton JH, Thamm DH, Withrow SJ and Lana SE: Comparison of carboplatin and doxorubicin-based chemotherapy protocols in $470 \mathrm{dogs}$ after amputation for treatment of appendicular osteosarcoma. J Veterin Internal Med 28: 554-563, 2014.

6. Reddy KI, Wafa H, Gaston CL, Grimer RJ, Abudu AT, Jeys LM, Carter SR and Tillman RM: Does amputation offer any survival benefit over limb salvage in osteosarcoma patients with poor chemonecrosis and close margins? Bone Joint J 97-B: 115-120, 2015.

7. Ferrari S and Serra M: An update on chemotherapy for osteosarcoma. Exp Opin Pharmacother 16: 2727-2736, 2015.

8. Wang WG, Wan C and Liao GJ: The efficacy of high-dose versus moderate-dose chemotherapy in treating osteosarcoma: A systematic review and meta-analysis. In J Clin Exp Med 8: 15967-15974, 2015.

9. Zhang FY, Tang W, Zhang ZZ, Huang JC, Zhang SX and Zhao XC: Systematic review of high-dose and standard-dose chemotherapies in the treatment of primary well-differentiated osteosarcoma. Tum Biol 35: 10419-10427, 2014.

10. Ta HT, Dass CR, Choong PF and Dunstan DE: Osteosarcoma treatment: State of the art. Cancer Metastasis Rev 28: 247-263, 2009. 
11. Tang N, Song WX, Luo J, Haydon RC and He TC: Osteosarcoma development and stem cell differentiation. Clin Orthop Rel Res 466: 2114-2130, 2008.

12. Siegel R, Naishadham D and Jemal A: Cancer statistics, 2013. CA Cancer J Clin 63: 11-30, 2013.

13. Allen JI and Moore MN: Environmental prognostics: Is the current use of biomarkers appropriate for environmental risk evaluation? Mar Environ Res 58: 227-232, 2004.

14. Chaturvedi S and McCrae KR: Clinical risk assessment in the antiphospholipid syndrome: Current landscape and emerging biomarkers. Curr Rheumatol Rep 19: 43, 2017.

15. Moutzouri E, Tsimihodimos V and Tselepis AD: Inflammatory biomarkers and cardiovascular risk assessment. Current knowledge and future perspectives. Curr Pharm Design 19: 3827-3840, 2013.

16. Dijkstra S, Mulders PF and Schalken JA: Clinical use of novel urine and blood based prostate cancer biomarkers: A review. Clin Biochem 47: 889-896, 2014.

17. Kai K, Dittmar RL and Sen S: Secretory microRNAs as biomarkers of cancer. Semin Cell Develop Biol, 2017.

18. Li S, Liu X, Liu T, Meng X, Yin X, Fang C, Huang D, Cao Y, Weng $\mathrm{H}$, Zeng $\mathrm{X}$ and Wang $\mathrm{X}$ : Identification of Biomarkers Correlated with the TNM Staging and Overall Survival of Patients with Bladder Cancer. Front Physiol 8: 947, 2017.

19. Van Loon K and Venook AP: Biomarkers in colon cancer: The chasm between expectations and reality. Oncology (Williston Park) 27: 758, 763, 2013.

20. Senger DR, Wirth DF and Hynes RO: Transformed mammalian cells secrete specific proteins and phosphoproteins. Cell 16 885-893, 1979.

21. Franzen A and Heinegard D: Isolation and characterization of two sialoproteins present only in bone calcified matrix. Biochem J 232: 715-724, 1985.

22. Rangaswami H, Bulbule A and Kundu GC: Osteopontin: Role in cell signaling and cancer progression. Trends Cell Biol 16: 79-87, 2006.

23. Kazanecki CC, Uzwiak DJ and Denhardt DT: Control of osteopontin signaling and function by post-translational phosphorylation and protein folding. J Cell Biochem 102: 912-924, 2007.

24. Tuck AB, Chambers AF and Allan AL: Osteopontin overexpression in breast cancer: Knowledge gained and possible implications for clinical management. J Cell Biochem 102: 859-868, 2007.

25. Cao DX, Li ZJ, Jiang XO, Lum YL, Khin E, Lee NP, Wu GH and Luk JM: Osteopontin as potential biomarker and therapeutic target in gastric and liver cancers. World J Gastroenterol 18 3923-3930, 2012.

26. Denhardt DT and Guo X: Osteopontin: A protein with diverse functions. FASEB J 7: 1475-1482, 1993

27. El-Tanani MK: Role of osteopontin in cellular signaling and metastatic phenotype. Front Biosci 13: 4276-4284, 2008.

28. Boldrini L, Donati V, Dell'Omodarme M, Prati MC, Faviana P, Camacci T, Lucchi M, Mussi A, Santoro M, Basolo F and Fontanini G: Prognostic significance of osteopontin expression in early-stage non-small-cell lung cancer. Brit J Cancer 93 . 453-457, 2005.

29. Chambers AF, Wilson SM, Kerkvliet N, O'Malley FP, Harris JF and Casson AG: Osteopontin expression in lung cancer. Lung Cancer 15: 311-323, 1996.

30. Hu Z, Lin D, Yuan J, Xiao T, Zhang H, Sun W, Han N, Ma Y, Di X, Gao M, et al: Overexpression of osteopontin is associated with more aggressive phenotypes in human non-small cell lung cancer. Clin Cancer Res 11: 4646-4652, 2005.

31. Mack PC, Redman MW, Chansky K, Williamson SK Farneth NC, Lara PN Jr, Franklin WA, Le QT, Crowley JJ and Gandara DR; SWOG: Lower osteopontin plasma levels are associated with superior outcomes in advanced non-small-cell lung cancer patients receiving platinum-based chemotherapy: SWOG Study S0003. J Clin Oncol 26: 4771-4776, 2008.

32. Ostheimer C, Bache M, Guttler A, Reese T and Vordermark D: Prognostic information of serial plasma osteopontin measurement in radiotherapy of non-small-cell lung cancer. BMC Cancer 14: 858, 2014

33. Ostheimer C, Gunther S, Bache M, Vordermark D and Multhoff G: Dynamics of heat shock protein 70 serum levels as a predictor of clinical response in non-small-cell lung cancer and correlation with the hypoxia-related marker osteopontin. Front Immunol 8: 1305, 2017.

34. Ostheimer C, Schweyer F, Reese T, Bache M and Vordermark D The relationship between tumor volume changes and serial plasma osteopontin detection during radical radiotherapy of non-small-cell lung cancer. Oncology Lett 12: 3449-3456, 2016.
35. Schneider S, Yochim J, Brabender J, Uchida K, Danenberg KD, Metzger R, Schneider PM, Salonga D, Hölscher AH and Danenberg PV: Osteopontin but not osteonectin messenger RNA expression is a prognostic marker in curatively resected non-small cell lung cancer. Clin Cancer Res 10: 1588-1596, 2004.

36. Shi L and Wang X: Role of osteopontin in lung cancer evolution and heterogeneity. Sem Cell Develop Biol 64: 40-47, 2017.

37. Wang M, Han J, Marcar L, Black J, Liu Q, Li X, Nagulapalli K, Sequist LV, Mak RH, Benes CH, et al: Radiation Resistance in kras-mutated lung cancer is enabled by stem-like Properties Mediated by an Osteopontin-EGFR Pathway. Cancer Res 77: 2018-2028, 2017.

38. Anborgh PH, Caria LB, Chambers AF, Tuck AB, Stitt LW and Brackstone M: Role of plasma osteopontin as a biomarker in locally advanced breast cancer. Am J Transl Res 7: 723-732, 2015.

39. Das R, Mahabeleshwar GH and Kundu GC: Osteopontin stimulates cell motility and nuclear factor kappaB-mediated secretion of urokinase type plasminogen activator through phosphatidylinositol 3-kinase/Akt signaling pathways in breast cancer cells. J Biol Chem 278: 28593-28606, 2003.

40. Gu M and Zheng X: Osteopontin and vasculogenic mimicry formation are associated with response to neoadjuvant chemotherapy in advanced breast cancer. OncoTargets Ther 10: 4121-4127, 2017

41. Psyrri A, Kalogeras KT, Wirtz RM, Kouvatseas G, Karayannopoulou G, Goussia A, Zagouri F, Veltrup E, Timotheadou E, Gogas H, et al: Association of osteopontin with specific prognostic factors and survival in adjuvant breast cancer trials of the hellenic cooperative oncology group. J Transl Med 15: 30, 2017.

42. Tuck AB and Chambers AF: The role of osteopontin in breast cancer: Clinical and experimental studies. J Mamm Gland Biolo Neopl 6: 419-429, 2001.

43. Zduniak K, Agrawal A, Agrawal S, Hossain MM, Ziolkowski P and Weber GF: Osteopontin splice variants are differential predictors of breast cancer treatment responses. BMC Cancer 16: 441,2016

44. Ding L and Zheng S: Expression and clinical significance of osteopontin in colorectal cancer and liver metastatic tissues. Zhonghua wai ke za zhi 40: 773-775, 2002 (In Chinese).

45. Ding L, Zheng S and Cao J: Expression of osteopontin mRNA and its protein in colorectal cancer and liver metastatic tissues. Zhonghua yi xue za zhi 82: 970-973, 2002 (In Chinese).

46. Gu X, Gao XS, Ma M, Qin S, Qi X, Li X, Sun S, Yu H, Wang W and Zhou D: Prognostic significance of osteopontin expression in gastric cancer: A meta-analysis. Oncotarget 7: 69666-69673, 2016.

47. Imano M, Okuno K, Itoh $\mathrm{T}$, Satou $\mathrm{T}$, Ishimaru E, Yasuda $\mathrm{T}$, Hida J, Imamoto H, Takeyama Y and Shiozaki H: Osteopontin induced by macrophages contribute to metachronous liver metastases in colorectal cancer. Am Surg 77: 1515-1520, 2011.

48. Ito T, Hashimoto Y, Tanaka E, Kan T, Tsunoda S, Sato F, Higashiyama M, Okumura T and Shimada Y: An inducible short-hairpin RNA vector against osteopontin reduces metastatic potential of human esophageal squamous cell carcinoma in vitro and in vivo. Clin Cancer Res 12: 1308-1316, 2006.

49. Kolb A, Kleeff J, Guweidhi A, Esposito I, Giese NA, Adwan H, Giese T, Büchler MW, Berger MR and Friess H: Osteopontin influences the invasiveness of pancreatic cancer cells and is increased in neoplastic and inflammatory conditions. Canc Biol Ther 4: 740-746, 2005.

50. Lazar M, Sullivan J, Chipitsyna G, Gong Q, Ng CY, Salem AF, Aziz T, Witkiewicz A, Denhardt DT, Yeo CJ and Arafat HA Involvement of osteopontin in the matrix-degrading and proangiogenic changes mediated by nicotine in pancreatic cancer cells. J Gastroint Surgery 14: 1566-1577, 2010.

51. Li JJ, Li HY and Gu F: Diagnostic significance of serum osteopontin level for pancreatic cancer: A meta-analysis. Gen Test Mol Biomarkers 18: 580-586, 2014.

52. Lin J, Myers AL, Wang Z, Nancarrow DJ, Ferrer-Torres D, Handlogten A, Leverenz K, Bao J, Thomas DG, Wang TD, et al: Osteopontin (OPN/SPP1) isoforms collectively enhance tumor cell invasion and dissemination in esophageal adenocarcinoma. Oncotarget 6: 22239-22257, 2015.

53. Liu G, Fan X, Tang M, Chen R, Wang H, Jia R, Zhou X, Jing W, Wang H, Yang Y, et al: Osteopontin induces autophagy to promote chemo-resistance in human hepatocellular carcinoma cells. Cancer Lett 383: 171-182, 2016. 
54. Loosen SH, Roderburg C, Kauertz KL, Pombeiro I, Leyh C, Benz F, Vucur M, Longerich T, Koch A, Braunschweig T, et al: Elevated levels of circulating osteopontin are associated with a poor survival after resection of cholangiocarcinoma. J Hepatology 67: 749-757, 2017.

55. Ng L, Wan T, Chow A, Iyer D, Man J, Chen G, Yau TC, Lo O, Foo CC, Poon JT, et al: Osteopontin overexpression induced tumor progression and chemoresistance to oxaliplatin through induction of stem-like properties in human colorectal cancer Stem Cells Int 2015: 247892, 2015.

56. Sulpice L, Rayar M, Desille M, Turlin B, Fautrel A, Boucher E, Llamas-Gutierrez F, Meunier B, Boudjema K, Clément B and Coulouarn C: Molecular profiling of stroma identifies osteopontin as an independent predictor of poor prognosis in intrahepatic cholangiocarcinoma. Hepatology 58: 1992-2000, 2013.

57. Terashi T, Aishima S, Taguchi K, Asayama Y, Sugimachi K, Matsuura S, Shimada M, Maehara S, Maehara Y and Tsuneyoshi M: Decreased expression of osteopontin is related to tumor aggressiveness and clinical outcome of intrahepatic cholangiocarcinoma. Liver Int 24: 38-45, 2004.

58. Ue T, Yokozaki H, Kitadai Y, Yamamoto S, Yasui W, Ishikawa T and Tahara E: Co-expression of osteopontin and CD44v9 in gastric cancer. Inte J Cancer 79: 127-132, 1998.

59. Weber CE, Erşahin CH, Kuo PC and Mi Z: Pancreatic Cancer and Osteopontin: The Relationship Remains Unclear. Pancreas 45 e35-e36, 2016.

60. Wu H, Zhang H, Hu LY, Zhang TY, Zheng YJ, Shen F and Yang T: Is osteopontin a promising prognostic biomarker for cholangiocarcinoma? J Hepatol: Sep 20, 2017 (Epub ahead of print).

61. Wu IC, Wu MT, Chou SH, Yang SF, Goan YG, Lee JM, Chou YP, Bair MJ, Wang TE, Chen A, et al: Osteopontin expression in squamous cell cancer of the esophagus. World J Surg 32: 1989-1995, 2008.

62. Zhang HZ, Liu JG, Wei YP, Wu C, Cao YK and Wang M: Expressions of RhoC and osteopontin in esophageal squamous carcinoma and association with the patients' prognosis. Nan Fang Yi Ke Da Xue Xue Bao 26: 1612-1615, 2006 (in Chinese).

63. Forootan SS, Foster CS, Aachi VR, Adamson J, Smith PH, Lin K and $\mathrm{Ke} \mathrm{Y}$ : Prognostic significance of osteopontin expression in human prostate cancer. Int J Cancer 118: 2255-2261, 2006.

64. Hsieh IS, Huang WH, Liou HC, Chuang WJ, Yang RS and Fu WM Upregulation of drug transporter expression by osteopontin in prostate cancer cells. Mol Pharmacol 83: 968-977, 2013.

65. Puzone R, Paleari L, Montefiore F, Ruggiero L, Puntoni M, Maffezzini M, Bobbio B, Marroni P, Libener R and Betta PG: Osteopontin plasma level does not detect prostate cancer in patients referred for diagnostic prostate biopsy. Int J Biol Markers 25: 200-206, 2010.

66. Tilli TM, Bellahcène A, Castronovo V and Gimba ER: Changes in the transcriptional profile in response to overexpression of the osteopontin-c splice isoform in ovarian (OvCar-3) and prostate (PC-3) cancer cell lines. BMC Cancer 14: 433, 2014.

67. Tilli TM, Silva EA, Matos LC, Faget DV, Dias BF, Vasconcelos JS, Yokosaki Y and Gimba ER: Osteopontin is a tumor autoantigen in prostate cancer patients. Oncol Lett 2: 109-114, 2011.

68. Tozawa K, Yamada Y, Kawai N, Okamura T, Ueda K and Kohri K: Osteopontin expression in prostate cancer and benign prostatic hyperplasia. Urol Int 62: 155-158, 1999.

69. Hu ZD, Wei TT, Yang M, Ma N, Tang QQ, Qin BD, Fu HT and Zhong RQ: Diagnostic value of osteopontin in ovarian cancer: A meta-analysis and systematic review. PLoS One 10: e0126444, 2015.

70. Leung DT, Lim PL, Cheung TH, Wong RR, Yim SF, Ng MH, Tam FC, Chung TK and Wong YF: Osteopontin fragments with intact thrombin-sensitive site circulate in cervical cancer patients. PLoS One 11: e0160412, 2016.

71. Song JY, Lee JK, Lee NW, Yeom BW, Kim SH and Lee KW: Osteopontin expression correlates with invasiveness in cervical cancer. Aust N Z J Obstet Gynaecol 49: 434-438, 2009.

72. Wong JPC, Wei R, Lyu P, Tong OLH, Zhang SD, Wen Q, Yuen HF, El-Tanani $\mathrm{M}$ and Kwok HF: Clinical and in vitro analysis of Osteopontin as a prognostic indicator and unveil its potential downstream targets in bladder cancer. Int J Biol Sci 13: 1373-1386, 2017.

73. Xu C, Li H, Yin M, Yang T, An L and Yang G: Osteopontin is involved in TLR4 pathway contributing to ovarian cancer cell proliferation and metastasis. Oncotarget 8: 98394-98404, 2017.

74. Xu ST, Guo C, Ding X, Fan WJ, Zhang FH, Xu WL and Ma YC: Role of osteopontin in the regulation of human bladder cancer proliferation and migration in T24 cells. Mol Med Rep 11: 3701-3707, 2015.
75. Zivny JH, Leahomschi S, Klener P Jr., Zivny J, Haluzik M and Cibula D: Comparison of Plasma Osteopontin Levels between patients with borderline ovarian tumours and serous ovarian carcinoma. Folia Biol (Praha) 62: 258-262, 2016.

76. Jia R, Liang Y, Chen R, Liu G, Wang H, Tang M, Zhou X, Wang H, Yang Y, Wei $\mathrm{H}$, et al: Osteopontin facilitates tumor metastasis by regulating epithelial-mesenchymal plasticity. Cell Death Dis 7: e2564, 2016.

77. Bandopadhyay M, Bulbule A, Butti R, Chakraborty G, Ghorpade P, Ghosh P, Gorain M, Kale S, Kumar D, Kumar S, et al: Osteopontin as a therapeutic target for cancer. Exp Opin Therap Targ 18: 883-895, 2014.

78. Raja R, Kale S, Thorat D, Soundararajan G, Lohite K, Mane A, Karnik S and Kundu GC: Hypoxia-driven osteopontin contributes to breast tumor growth through modulation of HIF1 $\alpha$-mediated VEGF-dependent angiogenesis. Oncogene 33: 2053-2064, 2014.

79. Wei R, Wong JPC and Kwok HF: Osteopontin-a promising biomarker for cancer therapy. J Cancer 8: 2173-2183, 2017.

80. Todaro M, Gaggianesi M, Catalano V, Benfante A, Iovino F, Biffoni M, Apuzzo T, Sperduti I, Volpe S, Cocorullo G, et al: $\mathrm{CD} 44 \mathrm{v} 6$ is a marker of constitutive and reprogrammed cancer stem cells driving colon cancer metastasis. Cell Stem Cell 14: 342-356, 2014.

81. Zhang N, Ying MD, Wu YP, Zhou ZH, Ye ZM, Li H and Lin DS: Hyperoside, a flavonoid compound, inhibits proliferation and stimulates osteogenic differentiation of human osteosarcoma cells. PLoS One 9: e98973, 2014.

82. Mortus JR, Zhang Y and Hughes DP: Developmental pathways hijacked by osteosarcoma. Ad Exp Med Biol 804: 93-118, 2014.

83. Luo X, Chen J, Song WX, Tang N, Luo J, Deng ZL, Sharff KA, He G, Bi Y, He BC, et al: Osteogenic BMPs promote tumor growth of human osteosarcomas that harbor differentiation defects. Lab Invest 88: 1264-1277, 2008.

84. Velupillai P, Sung CK, Tian Y, Dahl J, Carroll J, Bronson R and Benjamin T: Polyoma virus-induced osteosarcomas in inbred strains of mice: Host determinants of metastasis. PLoS Path 6: e1000733, 2010.

85. Liu SJ, Hu GF, Liu YJ, Liu SG, Gao H, Zhang CS, Wei YY, Xue Y and Lao WD: Effect of human osteopontin on proliferation, transmigration and expression of MMP-2 and MMP-9 in osteosarcoma cells. Chin Med J 117: 235-240, 2004.

86. Liu SJ, Zhang DQ, Sui XM, Zhang L, Cai ZW, Sun LQ, Liu YJ, Xue Y and Hu GF: The inhibition of in vivo tumorigenesis of osteosarcoma (OS)-732 cells by antisense human osteopontin RNA. Cell Mol Biol Lett 13: 11-19, 2008.

87. Berge G, Pettersen S, Grotterød I, Bettum IJ, Boye K and GM Ml: Osteopontin-an important downstream effector of S100A4-mediated invasion and metastasis. Int J Cancer 129: 780-790, 2011

88. Rankin EB and Giaccia AJ: The role of hypoxia-inducible factors in tumorigenesis. Cell Death Different 15: 678-685, 2008.

89. Macheda ML, Rogers S and Best JD: Molecular and cellular regulation of glucose transporter (GLUT) proteins in cancer. J Cell Phy 202: 654-662, 2005.

90. Vander Heiden MG, Cantley LC and Thompson CB: Understanding the Warburg effect: The metabolic requirements of cell proliferation. Science 324: 1029-1033, 2009.

91. Hsieh IS, Yang RS and Fu WM: Osteopontin upregulates the expression of glucose transporters in osteosarcoma cells. PLoS One 9: e109550, 2014

92. Song K, Liu N, Yang Y and Qiu X: Regulation of osteosarcoma cell invasion through osteopontin modification by miR-4262. Tum Biol 37: 6493-6499, 2016.

93. Noda M, Yoon K, Prince CW, Butler WT and Rodan GA: Transcriptional regulation of osteopontin production in rat osteosarcoma cells by type beta transforming growth factor. J Biol Chem 263: 13916-13921, 1988.

94. Wong IH, Chan AT and Johnson PJ: Quantitative analysis of circulating tumor cells in peripheral blood of osteosarcoma patients using osteoblast-specific messenger RNA markers: A pilot study. Clin Cancer Res 6: 2183-2188, 2000.

95. Sulzbacher I, Birner P, Trieb K, Lang S and Chott A: Expression of osteopontin and vascular endothelial growth factor in benign and malignant bone tumors. Virch Arch 441: 345-349, 2002.

This work is licensed under a Creative Commons Attribution-NonCommercial-NoDerivatives 4.0 International (CC BY-NC-ND 4.0) License. 